\title{
A Challenge of Vocational Education for Preparing Green Employment
}

\author{
Rustam Asnawi, Istanto Wahju Djatmiko \\ Department of Electrical Engineering Education, \\ Faculty of Engineering, Yogyakarta State University. \\ Karangmalang, Yogyakarta, INDONESIA 55281 \\ rustam@uny.ac.id
}

\begin{abstract}
Currently the vocational education has been oriented to the educational processes in which focusing on the development of the student in order to ready to work professionally and ready to improve their self-potential in particular field work. Meanwhile, today and future jobs in various business sectors and industry are still growing and developing towards green jobs. If there is no counter and solution for this growth of green jobs, then it would create a new gap between the output's competencies of vocational education and the qualification that needed by various business sector and industry. After studying some latest literatures, it was found that there is no any explicitly and concretely both concept and definition of green jobs in the vocational education curriculum (Curriculum 2013). Thus, this paper presents the urgent and such a challenge to change the philosophy of vocational education towards green jobs and ecology oriented.
\end{abstract}

Index Terms - green job, educational, vocational, philosophy

\section{Introduction}

Vocational education or vocational education and training (VET) is educational institution which dedicating for preparing students to obtain employment in a variety of job levels that based-on traditional handwork or oriented toward a particular type of job. Thus, in the context of Indonesia educational system and in accordance with Act No. 20, 2003 of the National Education System, there are two terms associated with education of the world of work oriented that are the vocational education in secondary education and vocational education in higher education [1]. Meanwhile, traditionally vocational education is education using competency-based approach with the primary objective is to prepare student to be ready to work [2]. Thus the concept of vocational education can be argued that vocational education is special education that organized for students to be ready to work in a productive and professional, also able to plan to develop a career in a particular area of expertise. Vocational educations prepare students to enter certain mid-level jobs that match the demands required by the world of work, and provide skills to students to develop themselves.

On the other hand, the rising environmental issues lately led to a variety of programs, policies and theories related to the environmental conservation. Various parties, whether from government, private, and academic sector often create programs that it's title begins with the word "green" which means as environmental friendly. Along with its growth, the industry and the business world today has begun to lead to perform activities that refer to ecology and has been oriented to the job's activities that are environmental friendly. Various industrial and enterprise sectors have incorporated ecological and environmentfriendly criteria in the requirements of qualifications (skill) certification for its employees.

According to the International Labor Organization green jobs are jobs that can be categorized as environmental conservation jobs, among others: reforestation activities, waste management, waste recycling, organic farming, planting mangroves, and various other environment-oriented jobs [3]. The basic principle of the implementation of green jobs was delivered by [4], how to start the work with care for the environment, job security awareness and also the industrial products impact awareness into the environment, so then resulting the growth of economic with environmentally sound and decent work for workers. Thus, green jobs are intended to raise public awareness, that there are variety of business fields which are profitable businesses and also preserve the environment.

If this growth does not anticipated by vocational education, of course, it would creating disastrous gap between graduate's skill qualifications and the requirement of employment (manpower) in industry/business world. Meanwhile, the various definitions of vocational education above can be understood that the concept of vocational education which including ecology-based and environmental-friendly have not been clearly and concretely defined. This paper presents some ideas (rational, importance and urgency) on today vocational education towards environmental-friendly (green jobs) oriented vocational education.

\section{Green Jobs Opportunities in Vocational Education (Vocational High School)}

Green jobs commonly is defined as work in agricultural, manufacturing, research and development, administrative, and services that contribute substantially to maintain and preserve the quality of the environment. In particular, but not exclusively, this includes jobs that help to protect ecosystems and biodiversity, reduction of energy consumption, materials and water through high-efficiency strategies, and minimizing or preventing the formation of all type of waste and pollution. There are approximately 75 jobs are included in the eco-friendly category [5]. Such jobs are the development of alternative energy, sewage and water treatment up to organic agricultural products. Mostly Indonesia has the potential abilities to develop all of jobs. The emergence of green jobs as new jobs sector, can be used as an alternative of job creation in Indonesia. This means 
that Indonesia has a great opportunity to develop a vision of environmental- friendly jobs.

Regarding the green jobs, actually since 1997 the Government of Indonesia has issued a number of regulations concerned with environmental management. Government Regulation No. 18/1999 on Management of Hazardous and Toxic Waste underlying the implementation of environmental- friendly industry [6], Regulation of the Minister of Energy and Mineral Resources number 02/2006 on Exploitation of Renewable Energy Power Plants (medium scale) [7], Government Regulation No. 26/2008 on National Spatial Management Plan, Government Regulation No. 01/2011 on the Determination of Transfer Function of Land and Food Sustainable Agriculture [8], and Government Regulation No. 28/2011 on Forest Protection [9].

In the service sector, tourism is moving towards green service industry. In 2012, the Ministry of Tourism and Creative Economy published a book on "Strategic Plan for Sustainable Tourism and Green jobs in Indonesia", collaboration with the International Labour Organization. The strategic plan describes a framework for sustainable tourism planning [10]. A number of key strategies and implementation strategies are offered to be used as a reference for achieving sustainability and the provision of decent work and environment-friendly in tourism sector. Green jobs are decent jobs and will reduce energy consumption, raw materials, limiting greenhouse gas emissions, minimizing waste \& pollution, and protecting/restoring ecosystems.

In industrial sector, the Law No. 23/1997 on Environmental Management becomes the reference to promote green industries in Indonesia. Moreover, for all type of business/industry, dumping waste into the public (common) area is no longer allowed, and monitoring of the activities being carried out by the government [11]. As a company listed on the district level, the operation of this law depends on the situation in their respective districts. Implementation at the ministerial level, Eco-industry Program has been launched which would give an award to the company that processes and/or convert (green) input into environmental-friendly products.

Based on the above description, it can be seen the jobs that are oriented towards environment-friendly have been implemented in various sectors boosted by the legislation. Obviously, this will have an impact and consequences of the emergence of a new competence qualification for potential employment when entering the workforce-world today and in the future. The competence and qualifications closely related to the mastery in ecology and environment friendly in such field. Also, this means that as well as the opportunities and challenges for managers and policy makers in vocational education. Vocational education as an education system based on competency strive the learning outcomes from vocational education has competencies, skills and expertise relevant to the needs of the market, including mastery of ecology and green jobs. As a skilled \& ready to work employee maker that working in various fields, vocational education world needs to adapt the philosophy that integrates the green jobs competence requirement inside the learning process.

\section{The Change of Vocational Education Philosophy towards Green Jobs}

There are two categories of vocational education philosophy, namely existentialism and essentialism. Existentialism holds that vocational education should develop human existence in order to survive, not seize it, while essentialism views that vocational education should associate itself with other systems such as economic, political, social, manpower, and religious as well as moral. Vocational education philosophy is simply stated by Thompson "what job was the need and what was needed to do the job"[12].

Based on the above philosophy of vocational education, it can be developed an idea that vocational education should be oriented to the direction and purpose of education on how to develop and establish the existence of survival for humans to observe and relate it to other systems, particularly the environment and its surrounding system. This means, adaptation of environmental friendly education into vocational education will embody a new philosophy as a consideration in the implementation of vocational education in the future.

The skill and expertise of human resources of Indonesia need to be improved. The change of policy in vocational education needs to be implemented soonly and should be oriented to the job market demand. As mentioned in the previous description, the current and future job market demand lead to the competence of job skill which enable to carry out green job. It means that inside the process of skill/competence building (when managing \& operating the vocational education) must include eco-friendly philosophy.

\section{Implication of Green Jobs in the Learning Process}

Environmental-friendly (green) skills and environmental awareness are becoming a priority and a challenge for vocational education in the present and the future. Competency standard is to measure the achievement of learning outcomes in the learning process in vocational education. Thus, the role of vocational education curriculum development towards environmental-friendly vision of education needs careful attention. The curriculum should be designed in accordance with the needs of the industry as a stakeholder oriented to Green Jobs. Consequently, schools should adjust the need for competence of green jobs as an indicator of the competence of its graduates

Meanwhile, currently the Indonesian government has been developing and implementing Curriculum 2013 for vocational secondary schools throughout Indonesia. The Indonesian government has issued formal regulations regarding the implementation of Curriculum 2013 for vocational secondary school through Regulation of the Minister of Education and Culture of the Republic of Indonesia No. 70/2013 on the Basic Framework and Curriculum Structure of the Vocational Secondary Schools [13]. According to the minister regulation in Article 1 stated that the basic framework of the vocational secondary school curriculum is the philosophical, sociological, pedagogical and juridical foundation that is functioned as a reference for developing the structure of curriculum at national level and developing the local content at the local level as well as guidelines for developing the curriculum of vocational secondary schools. The structure of the vocational secondary school curriculum is the organization of the core 
competencies, subjects, teaching loads and the basic competences in each vocational high school.

Furthermore related to the green jobs, after examining carefully the content of the minister regulation No. 70/2013, globally apparent that the Curriculum 2013 hasn't yet explained, covered, implemented, and integrated the concept of green jobs (at least concretely defined in basic competencies) [13]. Let's see in the definition section of the understanding of curriculum and the rational of curriculum development that have not yet explicitly incorporated the concept of green jobs expressly. In the rational of Curriculum 2013 development section, there are mentioned five basic factors of Curriculum 2013 development, namely: (1) internal challenges, (2) external challenges, (3) mindset improvement (completion), (4) strengthening the curriculum management, and (5) strengthening material. According to this five factors, only the third factor (mindset improvement) that mentioned the importance of natural environment awareness as cited as the following statement: "the one-way learning model (teacher-to-learner interaction) into an interactive learning model (interactive between teacher-learner-society-natural environments, other source/media)". Then the more important is in the defining of the characteristic of Curriculum 2013, there are mentioned seven characteristics of Curriculum 2013. Yet no one of those seven characteristics states clearly and unequivocally that the Curriculum 2013 would be characterized by consistently oriented towards ecology and insightful environmental-friendly. Then in the Curriculum Objectives section states that Curriculum 2013 is aimed for preparing the human of Indonesian to have the ability to live as a person and a believer citizen, productive, creative, innovative, affective and able to contribute to the society, nation, state, and world civilization. It is seen that the substance of the concept of green jobs have not been accommodated clearly and unequivocally. Of course, eventually this will bring consequences that the concept of green jobs is not clearly visible and defined in the development of the Basic Framework and Structure of Curriculum 2013.

Indeed, in the Basic Framework and Structure section of Curriculum 2013 there are a few items that have been mentioned explicitly on concerning the natural environment, but unfortunately it still has not been translated and elaborated at application level or in the basic competencies concretely and definitively. For an example, in the Philosophical Foundation section indicated there is an inconsistency between the concepts of Philosophical Foundation and the Philosophical Definition of Curriculum 2013. In the minister regulation is explained that a philosophical foundation for curriculum development will determine the quality of the students (learners) who will be achieved, the sources \& content of curriculum, the teaching learning process, the position of learners, learning outcomes assessment, student (learner) relationships with the community and the surrounding natural environment. However, the concept of "quality of learners with the community and the natural environment" does not appear and descripted explicitly, clearly and firmly in the definition of the development philosophy of Curriculum 2013. Later in the Theoretical Foundation section and also in the Juridical Foundation section of Curriculum 2013 there is no any statement that directly related to the substance of green jobs.
Meanwhile in the curriculum structure section is mentioned the Curriculum 2013 consists of: (a) Core Competencies (b) Subjects (c) Basic Competencies. The formulation of the core competencies using the following notation:

1. Core Competencies-1 (KI-1) for the core competencies of spiritual attitude

2. Core Competencies-2 (KI-2) for the core competencies of social attitudes

3. Core Competencies-3 (KI-3) for the core competencies of knowledge

4. Core Competencies-4 (KI-4) for the core competencies of skills.

Those of four formulations of the core competencies only the Core Competencies-2 (KI-2) explicitly mentioned jobs that aware to the natural environmental-friendly. However, the KI-1, KI-3 and KI-4 there is no any directly statements related to the environmental-friendly jobs. Then, the structure of the curriculum for vocational secondary school either for the three or four year curriculum were divided into three groups of subjects, namely:

a. Group A (mandatory) covers subjects: Religious \& Character Education, Pancasila and Citizenship Education, Indonesian Language, Math, History of Indonesia, and English.

b. Groups B (mandatory), includes: Arts \& Culture, Crafts \& Entrepreneurship, Physical Education, Sports and Health.

c. Groups C (specialization) which includes specialization in subjects of academic and vocational.

It is seen that in this structure of the curriculum of the vocational secondary school also there are not explicitly subjects that incorporate environmental-friendly jobs. Then, the basic competencies of Curriculum 2013 are formulated to achieve the core competencies. The formulation of the basic competencies was developed by taking into account the characteristics of learners, the initial capability of learners, as well as the characteristics of a subject. So the basic competencies of Curriculum 2013 were divided into four groups according to the grouping of the core competencies. Since the basic competencies were formulated to achieve the core competencies, so it is reasonable that there is no any basic competency formulation that incorporating and integrating the definition of the environmental-friendly job explicitly and clearly.

Furthermore, to support the successful implementation of Curriculum 2013, the Indonesian government through the Ministry of Education and Culture has undertaken various efforts to familiarize to teachers and also have issued other regulations to support the implementation of Curriculum 2013, such as the regulation of the Ministry of Education \& Culture No. 71/2013 which regulates for textbooks and teachers' handbook for Primary and Secondary School [14]. In the Appendix I regarding textbooks and Appendix II of teachers' handbooks there are mentioned the title of books for students and teachers that decent used in teaching-learning processes. Although the regulation is intended for primary and secondary school, however the spirit indeed is designed to support the implementation of Curriculum 2013 at primary school or vocational secondary school level. After examining the title of the book in the table, there was not found a title that directly related to the environmental-friendly (green) jobs. 
Finally, those of previous description can be highlighted that the concept of green jobs has not been concretely descripted and implemented in the Curriculum 2013. If this matter does not immediately followed up by real actions then it will cause further widening the gap between the competencies qualifications that required by industry in various sectors and the competency profiles of graduates who graduated from vocational secondary schools. To overcome these problems is not easy. It's required seriously and sustained effort from competent institutions or authorities which they have been aware and understood the importance of the application of green jobs in the philosophy of vocational education curriculum. The main challenge is emerging the awareness and understanding of decision maker level on the importance of applying the green jobs concept in the curriculum of vocational education concretely. The second is performing activities to socialize the importance of green jobs implementation in the development of vocational education curriculum for the executors of policy of the vocational education curriculum.

Third, for the technical executors of the curriculum policy that have been aware of the importance of green jobs application in the teaching-learning could apply a few items of the minister regulation number 70/2013 which has been declared explicitly to the importance of care for the natural environment. Jobs are concerned with the natural environment can be translated as ecological-based and environmental-friendly jobs. So, at least in application level, the teaching-learning of Curriculum 2013 a little more has touched and applied the substance of green jobs.

\section{Conclusion}

Jobs in various sectors of industry, both the services and manufacturing, are now beginning to be oriented towards green jobs. The Indonesian government, as the highest decision-makers on the jobs management in various sectors of industry, has also begun to establish some standards for sound and environmental-friendly jobs.

The problem is when the education world, especially vocational education which is a special institution to produce a ready-to-use employee in various sectors of industry, has not fully captured the opportunities. The philosophy of vocational education that is reflected in the current curriculum (Curriculum 2013), which has been announced by the Indonesian government to be implemented in vocational secondary schools throughout Indonesia has not clearly and expressly accommodated the application of the concept of green jobs. This matter if does not addressed and followed up immediately then could causing further widening the gap between competencies qualifications that required by industry and the graduates' competencies of vocational education.

Therefore, it needs quickly for performing efforts to update and change the philosophy of vocational education towards an environmental-friendly vocational education. It's an opportunity for all those who already understand and are aware of the importance of vocational education philosophy which is concerned to the green jobs.

\section{References}

[1]. Undang-undang nomor 20 Tahun 2003. Sistem Pendidikan Nasional. http://www.dikti.go.id/ files/atur/UU20-2003Sisdiknas.pdf, accessed $20^{\text {th }}$ April 2014.

[2]. Pavlova, M (2009). Technology and vocational education for sustainable development: Empowering individuals for the future. Springer, Australia.

[3]. International Labor Organization (2008). Green jobs: Facts and figures. http://www.ilo.org/ integration/greenjobs/index.htm., accessed $1^{\text {st }}$ April 2014.

[4]. Wahab Bangkona. (2012). Pengembangan green jobs butuh dukungan sosialisasi. http://www.centroone.com/news/2012/08/5y/ pengembangan-green-jobs- butuh- dukungan- sosialisasi, accessed $1^{\text {st }}$ April 2014.

[5]. Syarif Hidayatullah (2011). Green jobs, peluang, dan tantangan. http://ekonomi.kompasiana.com/bi sni s/2011/02/22/green- jobspeluang-dan-tantangan-341884.html, accessed $1^{\text {st }}$ April 2014.

[6]. Departemen ESDM (1999). Peraturan Pemerintah Nomor 18 tahun 1999, Pengelolaan Limbah Bahan Berbahava dan Beracun. http://prokum.esdm.go.id/pp/1999/PP18Tahun1999.pdf, accessed $20^{\text {th }}$ April 2014.

[7]. Kementerian ESDM (2006). Peraturan Menteri Energi dan Sumber Daya Mineral Nomor 002 tahun 2006. (2006). Pengusahaan Pembangkit Listrik Tenaga Energi Terbarukan Skala Menengah. http://prokum.esdm.go.id/permen/ 2006/permen-esdm-02-2006.pdf, accessed $20^{\text {th }}$ April 2014.

[8]. Kementerian ESDM (2006). Peraturan Pemerintah nomor 26 tahun 2008. (2008). Rencana Tata Ruang Wilayah Nasional. http://prokum.esdm.go.id/pp/2008/PP_26_2008.pdf, accessed: $20^{\text {th }}$ April 2014.

[9]. Peraturan Pemerintah Nomor 1 Tahun 2011. Penetapan dan Alih Fungsi Lahan Pertanian Pangan Berkelanjutan. http://www.presidenri.go.id/DokumenUU.php/581.pdf, accesed $20^{\text {th }}$ April 2014.

[10]. Kementerian Pariwisata dan Ekonomi Kreatif bekerjasama dengan International Labour Organization (2012). Rencana Strategis Pariwisata Berkelanjutan dan Green Jobs untuk Indonesia. ILO Country Office, Jakarta.

[11]. Undang-undang Nomor 23 Tahun 1997. Pengelolaan Lingkungan Hidup. http://bk.menlh.go.id/files/UU-2397.pdf, accesed $20^{\text {th }}$ April 2014.

[12]. Thompson, J.F (1973). Foundation of vocational education social and philosophical concepts. Prentice-Hall, New Jersey:

[13]. Kemdikbud (2013). Peraturan Menteri Pendidikan dan Kebudayaan Nomor 70 tahun 2013, Kerangka Dasar dan Struktur Kurikulum Sekolah Menengah Kejuruan/Madrasah Aliyah Kejuruan. Berita Negara Republik Indonesia, Jakarta.

[14]. Kemdikbud (2013). Peraturan Menteri Pendidikan dan Kebudayaan Nomor 71 tahun 2013, Buku Teks Pelajaran dan Buku Panduan Guru untuk Pendidikan Dasar dan Menengah. Berita Negara Republik Indonesia, Jakarta 